\title{
Method of decision-making the proactive project management of organizational development
}

\author{
Dombrowski M. ${ }^{1}$, Dombrowski Z. ${ }^{1}$, Sachenko A. ${ }^{2,3}$, Sachenko O. ${ }^{1}$ \\ ${ }^{1}$ Department for Information Computer Systems and Control, \\ Ternopil National Economic University, \\ 3 Peremoga Square, 46009, Ternopil, Ukraine \\ ${ }^{2}$ Department for Informatics, \\ Kazimierz Pulaski University of Technology and Humanities in Radom, \\ 29 Malczewski Str., 26-600, Radom, Poland \\ ${ }^{3}$ Research Institute for Intelligent Computer Systems, \\ Ternopil National Economic University, \\ 3 Peremoga Square, 46009, Ternopil, Ukraine
}

(Received 20 November 2018; Revised 28 January 2019; Accepted 28 January 2019)

\begin{abstract}
Modern requirements to competitiveness, especially in the leading industries, set the priority of the development of enterprises in the energy sector. Projecting the organizational development of power supplying companies are considered as a complex problem, which has the various technical and organizational components, the implementation of which involves non-trivial approaches and increased costs. Therefore, to manage these projects is advisable to use a proactive approach and develop the specially adapted models and methods within the proactive management. In order to ensure decision-making on the managing the power supplying company transformation project, it is necessary to develop the predictability of the parameters of the project implementation processes. The estimation of the status of the project implementation is carried out according to the value of the indicator: the amount of project work. In the experimental study, the productivity and effectiveness of the proactive managing the power supplying company transformation project in Ukraine are considered to check the the proposed method adequacy. Consequently, the experimental study proves that to solve the proactive managing problem of the organizational development project based on the proposed method is not to identify the detected deviations but to determine their magnitude and acceptability in terms of achieving the goal of the project, allows a minimum upper limit for relative deviations from all the maximum values of the target functions obtained as a result of the solution, that is more effective than the known methods. Thus, the proposed method improves development of observation of deviations in the field of "chaotic proximity", their identification regarding the actual state of the system, and manageability of the project implementation by developing appropriate actions: stabilization, balancing or maneuvering for achieving the goal.
\end{abstract}

Keywords: proactive project management, organizational development, decision-making, power supplying company, strategy, proactive managing.

2000 MSC: $90 \mathrm{~B} 50$

UDC: 338.28

DOI: $10.23939 / \mathrm{mmc} 2019.01 .014$

\section{Introduction}

The main task of any country's economic growth is to increase its competitiveness and create competitive enterprises, especially in the leading industries. The growth of the domestic economy requires the priority development of power supply companies in Ukraine through transformation, the level of efficiency of which has a significant impact on all sectors. Implementation of the enterprise development strategy is based on projects [1]. 
But according to [2] changes and transformations in themselves do not necessarily represent a stumbling block for the researcher. Rather studying crucial projects provides a means for studying the mechanisms at work in the host organization.

Common processes of Project Management [3] are not suitable for projects of organizational design and development. Projects of organizational development, for example for power supplying companies and their environment have features that distinguish them from other types of projects. They are considered as complex, having the various technical and organizational components, the implementation of which involves non-trivial approaches and increased costs [4,5]. On a long way towards achieving the purpose of managing those projects mistakes can lead to unacceptable results. Therefore, to manage such a project as a complex organizational and technical system, it is advisable to use a proactive approach that can reduce both planning and operational errors [6], and develop the specially adapted models and methods within the proactive management [7].

The task of the proactive project management that is solved at the pre-planning stage is the establishment of a conceptual action plan of the project that will reflect the chosen scenario of transforming the development strategy from the state of "how is" $\left(S_{0}\right)$ to the state "as it should be" $\left(S_{n}\right)$ i.e. into the projects product. Then at the same time to solve the problem of achieving the goal of the system, the project product must perform administrative actions so that for the time defined in the project $T$ in series for $n$ stages (phases), transfer the system from the state $S_{0}, x(0)=x_{0}$, to the state $S_{n}$, $x(T)=x_{T}$, so that expenses are within the budget.

For successful implementation of the project, that is, its implementation in time and within the approved budget, project planning is necessary but insufficient, it is necessary to continuously monitor the implementation of planned tasks and, on the basis of this information, to build forecasts at each stage of the life phase of the project and to take the necessary actions for implementation adjustment. Consequently, the effectiveness and efficiency of the management of an organizational development project depends on an adequate determination of the status of the $S_{k}$ system at the $k$-th step and the timeliness of decision-making. Thus, the task of operations management of the project appears in the phase of its realization. The main purpose of operations management of projects in the phase of its implementation is to ensure timely performance of planned indicators. Operations project management is part of the overall project management system, between the elements (systems) of which there are links and the ability to change the tasks previously set. That is, in case of any violation of the project implementation, decisions are made on actions aimed at reducing the deviation from the plan taking into account changes in the environment [8].

The effectiveness of proactive management of project implementation is not to identify the deviations detected, but to determine their magnitude and acceptability in terms of achieving the goal of project implementation. Monitoring the change of time parameters, along with controlling the change in cost parameters, enables to predict the negative effects and take a series of measures aimed at achieving the ultimate goal of the project. There are determined permissible limits of deviations based on the characteristics of the project itself and the impact of these deviations on the risk of achieving the ultimate goal of the project $[9,10]$.

In [11] models of management programs for organizational development are considered in conditions of uncertainty of vision of projects and dynamics of the environment. In [12], strategic approaches to proactive planning of the distribution of resources for project work under uncertainty [13] are offered, and the need to develop a proactive basic chart to minimize weighted instability is emphasized. However, nobody used proactive project management for the power supplying company's organizational development and design.

So, a goal of this paper is to develop a decision-making method for a specially adapted proactive management project for organizational development in the power supplying company environment. 


\section{Proposed method}

In the proactive approach to determine the parameters of optimal motion to the goal in our opinion, it is advisable to make a decision on the basis of some dominant functional based on the analysis and evaluation of options in the vicinity of its optimum in the area of "chaotic proximity" (critical parameters) of the indicators of the processes of project execution [14].

Let us assume the project is characterized by a number of indicators $J_{0}\left(x_{0}\right), J_{1}\left(x_{0}\right), J_{2}\left(x_{0}\right), \ldots$, $J_{N}\left(x_{0}\right)$, and when making decisions, it is necessary to choose the parameters - the vector $x$ - so as to ensure that the conditions $J_{i}(x)=\min , i=0,1,2, \ldots, N$. Consider the problem in which the functional $J_{0}$ stands for the project cost, which should not exceed the value of its smallest possible value $J_{0}\left(x_{0}\right)$. Denote by $x_{0}$ the solution of the problem $J_{0}(x)=$ min. If there is a restriction on the choice of $x$, then the condition of the form $J_{0}(x)<(1+k) J_{0}\left(x_{0}\right)$, where $0<k \ll 1$ is imposed.

Determining the minimum value of $J_{0}$ and a set of parameters - vector $x_{0}$, which implements this "selected" project, at the point $x_{0}$ we calculate other parameters: $J_{1}\left(x_{0}\right), J_{2}\left(x_{0}\right), \ldots, J_{N}\left(x_{0}\right)$. If the "selected" project according to a specific criterion, the cost minus will not satisfy the customer for the duration of the completion of the project, then such a project option will be inappropriate. However, when looking for a better option, we cannot depart from the minimum cost $J_{0}\left(x_{0}\right)$, because this min value in this case is a constraint.

We have to take into account this limitation above during the making a decision. For this purpose, we need to construct a grid of points in the vicinity of point $X_{0}$ according to the corresponding values of the functional:

$$
J_{0}(x)=(1+k) J_{0}\left(x_{0}\right),
$$

where numbers $k_{i}$ are known permissible values, for example, $0.1(10 \%)$; or $0.05 \ldots 0.2$. Then we calculate the values of the parameters $J_{i}(x), i=1,2, \ldots, N$ from the set of network points $x$ for admissible solutions. After that, in the neighborhood $x_{0}$, a certain subset of acceptable options is defined that satisfy all stakeholders of the project for the further analysis, and other options are excluded from the consideration.

Consequently, optimization of the organizational development project is to seek some of the best (in a certain sense of value) solution to the predetermined set of admissible control options in a given domain of permissible management influences that are implemented in such a way that the functional $F(J, v)$ in this region $M \subset \Omega$ reaches extreme values provided that the risks do not increase [10] $(x, y, z) \in \Omega \subset \mathbb{R}_{n} ; t \subset\left(t_{0}, t^{*}\right)$, where $t_{0}$ is the beginning and end of $t^{*}$ of the sequence. The acceptance of the final decision is based on the results of further analysis of options from a pre-selected subset of critical parameters for compliance with another restriction (the degree of risk) of Fig. 1.

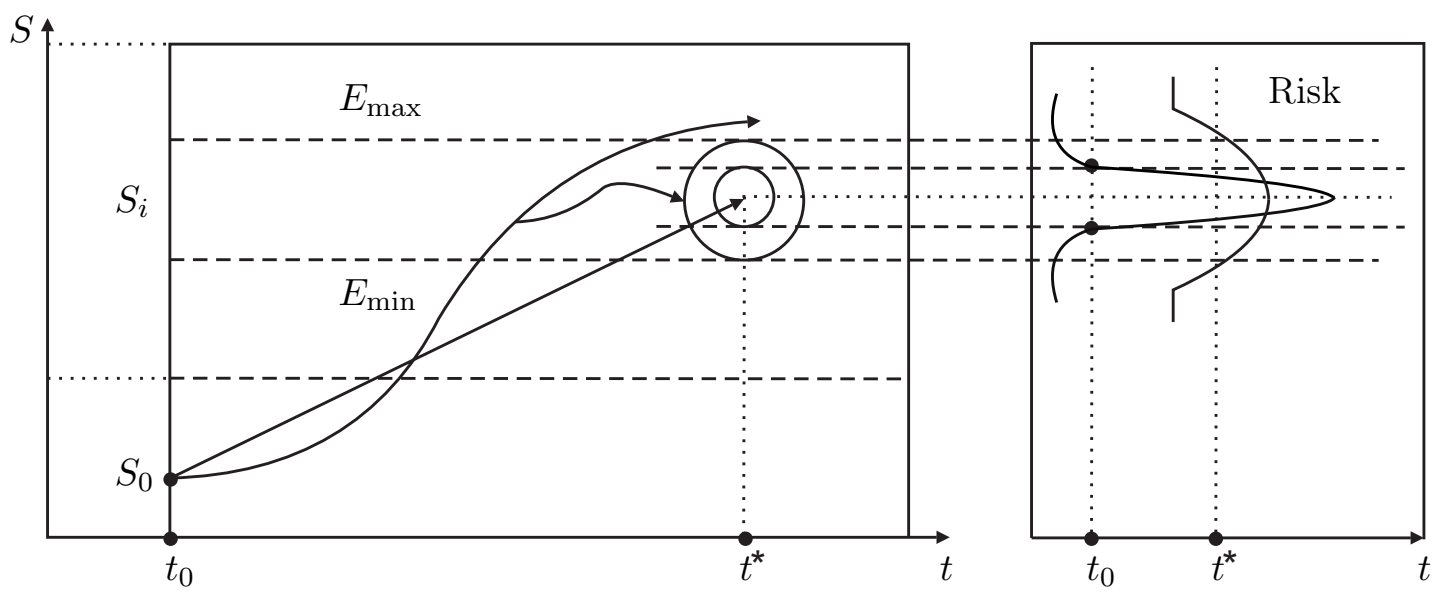

Fig. 1. Development of decision variants from a pre-selected subset with a risk assessment for failure to achieve the goal. 
Thus, the basis of solving the problem is the procedure for choosing an alternative path on the set of permissible trajectories [9], taking into account the limitations $\left(S_{i}\right)$, while the leading criterion is chosen to reduce the risk of failing to achieve the goal.

\section{Case study}

Let us consider the efficiency and effectiveness of the proposed proactive approach, for example, by managing the project of organizational development through the transformation of the Ukraine's power supplying companies.

In order to ensure decision-making on the management of the project of transformation of the power supplying company, it is necessary to form the vision of the product on the basis of the content of the project and, on this basis, develop the predictability of the parameters of the project implementation processes. Estimation of the status of the project implementation is estimated by the value of the indicator as the amount of project work (ARP).

Projects would often end up being successful if they highlighted the leading resource and increased attention to analysis and assessment of its impact on the results.

It should be noted that in the management of the system a project is a product of organizational development; two resources are intellectual and human. In organizational development projects, the main problem task is the planning of the required human resource, since other types of resources are easier to provide at the required level.

The main factors of the resources that determine the scope of project work are: $X_{1}$ is the number of personnel of the project team; $X_{2}$ is the average number of days spent by the staff; $X_{3}$ is total number of hours spent by the staff; $X_{4}$ is average salary; $X_{5}$ is productivity of work of one employee per hour; $X_{6}$ is the assets of the project.

Output data of factors for implementing the volume of work $Y$ projects are presented in Table 1.

Table 1. Options of project execution.

\begin{tabular}{|c|c|c|c|c|c|c|c|}
\hline Option & $X_{1}$ & $X_{2}$ & $X_{3}$ & $X_{4}$ & $X_{5}$ & $X_{6}$ & $Y$ (ARP) \\
\hline 1 & 20 & 90 & 8 & 14400 & 1500 & 45000 & 21645000 \\
\hline 2 & 12 & 72 & 7 & 6048 & 1170 & 40000 & 7116160 \\
\hline 3 & 5 & 20 & 8 & 800 & 1000 & 36000 & 836000 \\
\hline
\end{tabular}

According to the results of calculating the multiple regression (see a Table 1) using the linear approximation function of the least squares MS Excel are obtained the coefficients of the regression equation are obtained:

$$
Y_{m}=3726.9196 X_{4}-3319.6785 X_{6}+117362893
$$

Using the expression (2) we analyzed the variants of predicted values $\mathrm{Ym}$ at various values of the factors to make the decision according to the project management strategy. Parameters of the baseline vector to achieve the project goal (earned value) are selected in Table 2 like the "Base". The main results of changes influence for indicators on the volume of work performed are given in Table 2 .

The obtained results enable to construct control maps (Table 3) for making the project decision taking into account the risk, in this case the budget is value of planned costs (the assets of the project) $X_{6}$.

Thus, from the above experimental results, we can see the proposed method of making a decision in the proactive management of the project of organizational development of power companies with small values of changes in the basic indicators of the state of achievement of the goal improves:

- Development of observing the deviations in the field of "chaotic proximity", their identification regarding the actual state of the system; 
- Optimization of making possible decisions based on the assessment of acceptability degree for the actual operational state of the given risk;

- Manageability of the project implementation by developing appropriate actions: stabilization, balancing or maneuver for achieving the goal;

- Synthesis of informational-resource (financial) management space, which provides the greater quality control.

Table 2. Influence of indicators change on the basic volume of performed works.

\begin{tabular}{|c|c|c|c|c|c|c|c|}
\hline \multirow{3}{*}{ Scenario } & \multicolumn{6}{|c|}{ The main indicators that form the mastered volume } & \multirow[b]{2}{*}{ Forecast } \\
\hline & $\mathrm{N}$, labour & $\begin{array}{l}\text { Days spent } \\
\text { by the staff }\end{array}$ & Salary & $\begin{array}{l}\text { Salary } \\
\text { fundy }\end{array}$ & $\begin{array}{l}\text { Producti- } \\
\text { vity }\end{array}$ & $\begin{array}{c}\begin{array}{c}\text { Planned } \\
\text { volume }\end{array}\end{array}$ & \\
\hline & $X_{1}$ & $X_{2}$ & $X_{3}$ & $X_{4}$ & $X_{5}$ & $X_{6}$ & $\overline{Y(\mathrm{ARP})}$ \\
\hline Base & 16 & 3462 & 1.167 & 14.31 & 224 & 453.4 & 453.4 \\
\hline decrease $X_{1}$ & 13 & 3462 & 1.167 & 14.31 & 224 & 453.4 & -230.8 \\
\hline increase $X_{1}$ & 21 & 3462 & 1.167 & 14.31 & 224 & 453.4 & 1593.9 \\
\hline decrease $X_{2}$ & 16 & 3400 & 1.167 & 14.31 & 224 & 453.4 & 417.5 \\
\hline increase $X_{2}$ & 16 & 3510 & 1.167 & 14.31 & 224 & 453.4 & 481.2 \\
\hline
\end{tabular}

Table 3. Adoption of final decision on the criterion of reducing the risk of failure to achieve the goal.

\begin{tabular}{|c|c|c|c|c|}
\hline Variant & $\begin{array}{c}\text { Volume executed } \\
\text { works (Table 2) }\end{array}$ & $\begin{array}{c}\text { The volume of } \\
\text { resources } X_{2}\end{array}$ & Risks & Note \\
\hline More & 481.2 & 3510 & Unacceptable & It significantly exceeds the budget \\
\hline Basic & 453.4 & 3462 & Acceptable & The goal is achievable \\
\hline Reduced & 417.5 & 3400 & Unacceptable & It significantly exceeds the budget \\
\hline
\end{tabular}

Improvement of control quality is achieved at the expense of a predetermined expansion for the space of states in the vicinity of the optimal value. This approach enables to form the mental space of decision-making in conflicts in the system based on the concept of interaction of reflection. It takes into account the trajectory of the resources balance in the formation of decision-making procedures when changing the behavior of achieving the goal (target) area. The last one is based on the initial state and risk, restrictions on the rate of resources exchange, the adequacy of reserves and their availability to compensate for deviations.

Consequently, the solution of the problem of proactive management of the organizational development project, based on the proposed method, enables obtaining a minimum upper limit for relative deviations from all the maximum values of the target functions obtained as the solution result.

\section{Conclusions}

The decision-making method for determining the parameters of proactive project management by the achievement of the organizational development goal is suggested. It is based on the analysis and evaluation options in the vicinity of the "chaotic proximity" (critical parameters) area of the project implementation processes indicators.

According to the proposed method, the decisions are taken as follows. First determine the dominant function of the organizational development project, namely the cost of the project. Next, the options in the range of the dominant functional values are analyzed and evaluated. The final decision is made by comparing the options in the vicinity of the dominant functional to the degree of achieving the ultimate goal risk.

Thus, the basis for the decision is the procedure for selecting alternatives on the set of permissible values in the vicinity of the dominant functional. There are taking into account the limitations of the budget reserve based on the criterion of the permissible risk for achieving an ultimate goal. 
[1] Cooke-Davies T. J., Arzymanow A. The maturity of project management in different industries: An investigation into variations between project management models. International Journal of Project Management. 21 (6), 471-478 (2003).

[2] Lundin R. A., Steinthyrsson R. S. Studying organizations as temporary. Scandinavian Journal of Management. 19 (2), 233-250 (2003).

[3] A Guide to the Project Management Body of Knowledge (PMBoK), fifth ed., Project Management Institute, USA, 2013.

[4] LiH., XuZ., XiongL., Liu Y. Robust proactive project scheduling model for the stochastic discrete time/cost trade-off problem. Discrete Dynamics in Nature and Society. 2015, Article ID 586087, 10 pages (2015).

[5] Verba V.A. Company development projects: problems and signs of identification. Scientific journal "Manager" Journal of the DNUU. 4 (50), 207-214 (2009), (in Ukrainian).

[6] Fangel M. Proactive Project Management. AEW Services, Richmond Hill, ON, USA (2015).

[7] Bushueva N. S., Mysnyk L. D., Olekseenko M. M. System formalization of the project management within proactive approach to the organization development. Project Management and Development of Production: Collection of Scientific Papers. 2 (30), 5-11 (2009), (in Russian).

[8] Song W., Kang D., Zhang J., XiH. Proactive project scheduling with time-dependent workability uncertainty. Proceedings of the 16th Conference on Autonomous Agents and MultiAgent Systems. 221-229 (2017).

[9] DombrowskiZ., Sachenko O., Dombrovskiy M., Rymar O. Model of project management based on system approach. 2013 IEEE 7th International Conference on Intelligent Data Acquisition and Advanced Computing Systems (IDAACS). 2, 587-590 (2013).

[10] Jonas V., Bone L. Interfacing earned value and risk management. Proceedings of the PMI Global Congress, EMEA, Marsailles, France (2012).

[11] Bushueva N. S. Mechanisms of matrix technologies of the proactive balanced management of organizational development programs. Project Management and Development of Production. 2 (50), 96-106 (2014), (in Russian).

[12] Lambrechts O., Demeulemeester E., Herroelen W. Proactive and reactive strategies for resource-constrained project scheduling with uncertain resource availabilities. Journal of scheduling. 11 (2), 121-136 (2008).

[13] Dorozhovets M., Bubela I. Computing uncertainty of the extreme values in random samples. International Journal of Computing. 15 (2), 127-135 (2016).

[14] Dombrowski M.Z., Sachenko A. O. The proactive management model of strategic development project on the energy supply companies in a turbulent environment. Bulletin of NTU "KhPI". Series: Strategic management, portfolio, program and project management. 2 (1224), 41-45 (2017), (in Ukrainian). 


\title{
Метод прийняття рішень проактивного управління проектами в організаційному розвитку
}

\author{
Домбровський M. ${ }^{1}$, Домбровський $3 .^{1}$, Саченко A. ${ }^{2,3}$, Саченко O. ${ }^{1}$ \\ ${ }^{1}$ Кафедра інформаційно-обчислювальних систем $і$ управління, \\ Тернопільсъкий національний економічний університет, \\ майдан Перемоги, 3, Тернопіль, 46009, Україна \\ ${ }^{2}$ Кафедра інформатики, \\ Технолого-гуманітарний університет в Радомі ім. Казимира Пулавсъкого, \\ вул. Мальчевського, 29, Радом, 26-600, Польща \\ ${ }^{3}$ Науково-дослідний інститут Інтелектуальних комп'ютерних систем, \\ майдан Перемоги, 3, Тернопіль, 46009, Україна
}

Сучасні вимоги до конкурентоспроможності, особливо в провідних галузях промисловості, вимагають пріоритетного розвитку підприємств у енергетичному секторі. Проекти організаційного розвитку енергопостачальних компаній - складна проблема 3 різними технічними та організаційними компонентами, реалізація яких передбачає нетривіальні підходи та збільшення витрат. Тому для управління цими проектами доцільно використовувати проактивний підхід та розробляти спеціально адаптовані моделі та методи в межах активного управління. Щоб забезпечити прийняття рішень щодо управління проектом трансформації енергопостачальної компанії, необхідно розробити параметри, що забезпечують передбачуваність процесу впровадження проекту. Стан реалізації проекту оцінюється за вартістю показника - суми проектної роботи. В експериментальному дослідженні розглянуто продуктивність та ефективність проактивного управління проектом організаційного розвитку трансформації енергопостачальних компаній України для перевірки адекватності запропонованого методу. Отже, експериментальне дослідження доводить, що вирішення проблеми проактивного управління проектом організаційного розвитку на основі запропонованого методу полягає не у визначенні виявлених відхилень. Саме визначення їх величини та прийнятності з погляду досягнення мети проекту дає змогу встановити мінімальну верхню межу для відносних відхилень від усіх максимальних значень цільових функцій, отриманих у результаті вирішення, що ефективніше за відомі методи. Отже, запропонований спосіб сприяє розвитку спостережень за відхиленнями в області "хаотичної близькості", їх ідентифікацією щодо фактичного стану системи та керованістю реалізації проекту розробленням відповідних заходів: стабілізації, балансування або маневрування для досягнення мети.

Ключові слова: проактивне управління проектами, організачійний розвиток, прийняття рішень, енергопостачальна компанія, стратегія, проактивне керування.

2000 MSC: $90 \mathrm{~B} 50$

УДК: 338.28 